\title{
Host Plant Resistance to Leafminers in Lettuce
}

\author{
Beiquan Mou ${ }^{1}$ and Yong-Biao Liu ${ }^{2}$ \\ U.S. Department of Agriculture, Agricultural Research Service, 1636 East Alisal Street, Salinas, CA 93905
} AdDITIONAL INDEX words. Liriomyza langei, Liriomyza huidobrensis, insect resistance, heritability, Lactuca sativa, Lactuca
serriola, Lactuca saligna, Lactuca virosa

\begin{abstract}
Leafminer (Liriomyza spp.) is a major insect pest of many important agricultural crops including lettuce (Lactuca sativa $\mathbf{L}$.). The goals of this study were to evaluate lettuce genotypes for resistance to leafminers and to estimate the heritabilities of leafminer-resistant traits in the field, to examine the association among different resistant traits, and to study the mechanism of leafminer resistance in lettuce. Seventy-eight lettuce accessions and $232 \mathrm{~F}_{2}$ plants of crosses were evaluated for leafminer stings and the production of pupae and flies in the field in 2001 and 2002 , and resistant genotypes were subjected to no-choice test. Wild species (Lactuca serriola $L_{\text {., }}$ L. saligna L., and $L$. virosa L.) had significantly fewer stings than cultivated lettuces. Among cultivated lettuces, sting densities were lowest on leaf lettuce and highest on romaine types. The sting results from the field were highly correlated with the results from insect cages $(r=0.770$ and 0.756 for 2001 and 2002 tests, respectively), suggesting that a cage test can be used to screen for resistance in the field. Broad-sense heritability estimates for stings per unit leaf area in the field were $81.6 \%$ and $67.4 \%$ for 2001 and 2002 tests, respectively. The number of pupae produced per plant or per leaf was moderately correlated with sting density but was not correlated with leaf weight. Results suggest that both antixenosis and antibiosis exist in lettuce germplasm and resistant genotypes from choice tests remain resistant under no-choice conditions. These findings suggest that genetic improvement of cultivated lettuce for leafminer resistance is feasible.
\end{abstract}

Leafminers are major insect pests of many important crops in the world (Parrella, 1987). The principal leafminer species affecting vegetables include Liriomyza brassicae, L. sativae Blanchard, L. trifolii (Burgess), L. huidobrensis (Blanchard), and L. langei. The predominant species in the major lettuce (Lactuca sativa L.) production areas in central California was believed to be $L$. huidobrensis (pea leafminer) until recently (Morgan et al., 2000). Scheffer and co-workers (2001) identified the leafminers in central California to be the morphologically cryptic species L. langei.

Leafminer damage occurs when adult flies puncture leaves to feed on plant sap and when females lay white, oval eggs within the leaf tissue. Adult stings appear as holes or bumps on the leaves. Adult feeding on cotyledons may stunt seedling growth. Larvae hatch from eggs and feed between upper and lower leaf surfaces. The winding, whitish tunnels or mines they create are initially narrow, but increase in width as the larvae grow. Damages caused by adult sting and larval mining of leaves reduce photosynthetic capacity, render lettuce leaves unmarketable, and provide an entrance for disease organisms. Larvae emerge from the mines after completing three instars and pupate in cracks in the soil or on the leaf surface. Adult flies emerge from pupae in about 8 to $11 \mathrm{~d}$. The entire life cycle can be completed in less than three weeks in warm weather and many generations are produced each year in California (University of California, 1992).

Chemical control of leafminers usually lasts only a short period of time, and adult control with contact insecticides is often ineffective because flies can easily move around and the treated field is subject to reinfestation from adjacent untreated crops and weeds (LeStrange et al., 1999). It has been well documented that

Received for publication 15 Nov. 2003. Accepted for publication 1 Jan. 2004. We would like to thank JoAnn Tanaka for technical assistance and Steve Fennimore for critical review and discussion of the manuscript. Mention of a trade name, proprietary product, or vendor does not constitute an endorsement, guarantee, or warranty by the U.S. Dept. of Agriculture and does not imply its approval to the exclusion of other products or vendors that may be suitable. This research was supported in part by grants from the California Lettuce Research Board.

'Research geneticist; to whom correspondence should be addressed; e-mail bmou@pw.ars.usda.gov.

${ }^{2}$ Research entomologist. leafminers can develop a high degree of resistance to a broad range of insecticides (Keil and Parrella, 1990; Mason et al., 1987; Parrella and Trumble, 1989). Therefore, it is essential to develop alternative strategies for leafminer management. Resistant varieties remain the most economical means of insect control. Their deployment could reduce the pesticide use, which may be beneficial to growers, consumers, and the environment. However, lettuce cultivars with high levels of resistance to leafminers are not currently available.

There are two types of insect resistance: antixenosis and antibiosis. Antixenosis (nonpreference) means that a plant has traits that make it unattractive to insect pests to feed or to lay their eggs. Screening for antixenotic resistance is usually carried out in choice tests where insects can choose among different plant genotypes for feeding or oviposition. Antibiosis refers to the host plants that have chemicals or other factors that adversely affect the insects feeding on them. When insects attack plants with this type of resistance, they die, lay fewer eggs, produce fewer young, or have slower rates of growth. Screening for antibiotic resistance is usually conducted in no-choice tests where insects are allowed to feed on only one plant genotype at a time.

Limited studies on leafminer resistance in vegetables have been reported. Erb et al. (1993) found larval antibiosis against $L$. trifolii in four interspecific hybrids of tomato, and adult antibiosis and antixenosis for feeding was partially a result of the plant's trichome exudates. No resistance to leafminers (L. trifolii) has been observed in cultivated celery, but an accession of a wild species, Apium prostratum, was found to be practically immune as no feeding or oviposition was observed (Trumble and Quiros, 1988). An accession from another wild species, A. nodiflorum, demonstrated substantial insect toxicity; few mines were observed and no larvae survived to the pupal stage (Trumble et al., 1990). In lettuce, female leafminers (L. trifolii) survived significantly longer and produced more stings and pupae on the cultivar 'Tall Guzmaine' than on three other cultivars (Nagata et al., 1998; Nuessly and Nagata, 1994). Mou and Liu (2003) evaluated lettuce germplasm in insect cages and found that leaf lettuce varieties showed less leafminer stings than head lettuce types, and an accession (PI 509525) from a wild species, L. saligna, had few stings and no flies emerged from it. 
The leafminer resistance in lettuce has not been studied under field conditions, and the mechanism of leafminer resistance in lettuce is also unknown. The purposes of present experiments were to evaluate lettuce genotypes for resistance to leafminers and to estimate the heritabilities of leafminer-resistant traits in the field, to examine the association among different resistance traits, and to study the mechanism of leafminer resistance in lettuce.

\section{Materials and Methods}

Choice TeSTS. Experiments were conducted at the Agricultural Research Station of the U.S. Department of Agriculture, Salinas, Calif. Thirty-five accessions from the lettuce germplasm collection maintained at the station were evaluated in 2001, and 54 accessions were evaluated in 2002. They were previously evaluated in insect cages (Mou and Liu, 2003) and include crisphead, leaf, romaine, butterhead, stem, Latin, Batavia, and primitive forms of lettuce, and wild species Lactuca serriola, L. saligna, and L. virosa from different geographic areas. Seeds were planted in Sunshine Plug 5 Growing Mix (Sun Gro Horticulture, Inc., Bellevue, Wash.) in plastic transplanting trays $(128$ cells, $3 \times 3 \times 5 \mathrm{~cm}$ in length $\times$ width $\times$ height) in greenhouse in May. Four weeks after planting, plants were transplanted in the field in a randomized complete block design with eight replications and each plot consisting of eight plants. Spacing was $30 \mathrm{~cm}$ between plants and $35 \mathrm{~cm}$ between rows on 1-m-wide double-row beds. Number of leafminer stings was counted in a $20-\mathrm{cm}^{2}$ leaf area with the highest sting density on a randomly selected plant in each plot with the aid of an optical glass binocular magnifier (OptiVisor, Donegan Optical Co., Lenexa, Kans.) 6 weeks after transplanting.

Mature $\mathrm{F}_{2}$ (derived from selfing hybrid $\mathrm{F}_{1}$ plants) plants from crosses among PI 169513, 'Bibb', 'Lobjoits', 'Lolla Rossa', 'Prizehead', 'Red Grenoble', 'Salinas', 'Salinas 88', 'Tiber', and 'Tom Thumb', in a breeding nursery were randomly selected in 2001 and 2002 to study associations among leafminer resistant traits. These plants were used because the parents of the crosses showed different levels of leafminer resistance in previous tests, and the $\mathrm{F}_{2}$ plants exhibited extensive variation and segregation of the resistant traits. $F_{2}$ seeds were planted in the field with a Planet, Jr. Jiffy Planter (no longer in production) at a depth of 1 $\mathrm{cm}$ in May. About 4 weeks after planting, plants were thinned to $30 \mathrm{~cm}$ between plants and $35 \mathrm{~cm}$ between rows on $1-\mathrm{m}$ wide double-row beds. In July 2001, five lower leaves were selected from each of $112 \mathrm{~F}_{2}$ plants and leafminer stings in a randomly selected $20 \mathrm{~cm}^{2}$ leaf area were counted for each leaf. Outer leaves of each plant were then harvested, weighed, and put into an $8-\mathrm{L}$ clay pot (25 cm in diameter and $25 \mathrm{~cm}$ in height) covered with polypropylene fabric before larvae emerged from leaves and became pupae. A $17 \times 10$-cm sticky card (Seabright Labs, Emeryville, Calif.) was taped on inside surface of the pot to catch emerging adult flies. Number of flies on each card was counted 6 weeks later. In July 2002, only leafminer stings in a $20-\mathrm{cm}^{2}$ leaf area with the highest sting density on each of the $120 \mathrm{~F}_{2}$ plants were counted to reduce the amount of work. The outer leaves of each plant were then harvested, weighed, and hung on bamboo sticks in a $19-\mathrm{L}$ round plastic bucket $(30 \mathrm{~cm}$ in diameter and 36 $\mathrm{cm}$ in height) covered with polypropylene fabric before larvae dropped down to bottom of the bucket to pupate. A $17 \times 10 \mathrm{~cm}$ sticky card was taped on inside surface of the bucket to catch emerging adult flies. The pupae in each bucket and flies on each card were counted 6 weeks later.

No-CHOICE TEST. Lettuce leaves with leafminer mines were collected from newly harvested fields around Salinas and hung in the shade to allow leafminer larvae to emerge from the leaves and pupate. Pupae were collected and put in plastic containers to allow the adult flies to emerge. Resistant (as judged by sting density) genotypes (PI 187238, PI 273597, PI 491178, PI 509525, and 'Red Grenoble') and susceptible genotypes ('Salinas' and 'Da Ye Wo Sun') in field tests were planted in $10 \times 10 \times 10 \mathrm{~cm}$ plastic pots in June 2002. A single 4-week-old plant was placed in an insect cage made from a $21-\mathrm{L}$ round plastic bucket $(30 \mathrm{~cm}$ in diameter and $44 \mathrm{~cm}$ in height). The bucket top and two side windows $(26 \times 18 \mathrm{~cm})$ were covered with polypropylene fabric. The buckets were arranged in blocks and replicated seven times. Thirty newly-emerged flies were released in each of the bucket cages to feed on the plant. Daily observations were made to record how long the flies survived in the cage. The period from initial release of flies in the bucket cage to the date no released flies were found alive was defined as the adult period. Seven days after the release of flies in the cage, number of leafminer stings was counted for the whole plant and in a $20-\mathrm{cm}^{2}$ leaf area with the highest sting density on the plant. Number of mines on the plant was counted $25 \mathrm{~d}$ after the fly release in cages. A $17 \times 10$ $\mathrm{cm}$ sticky card was taped on inside surface of the bucket cage to catch emerging adult flies and the flies on the card were counted 9 weeks after the initial fly release in cages.

DAta AnALYsis. Data were analyzed using the Analysis of Variance (ANOVA) and Correlation functions of Microsoft Excel (Microsoft Office 2001, MicrosoftCo., Redmond, Wash.). Means of different genotypes were compared by computing least significant differences (LSD). Means of different lettuce types were compared by constructing contrasts with $F$ tests (Petersen, 1985). From the 2001 and 2002 field transplanting experiments, broad-sense heritabilities $\left(h^{2}\right)$ for leafminer sting density were estimated from the components of variances (Singh and Chaudhary, 1977): $h^{2}=\sigma_{\mathrm{g}}^{2} /\left(\sigma_{\mathrm{g}}^{2}\right.$ $+\sigma_{\mathrm{e}}^{2}$ ) where $\sigma_{\mathrm{g}}^{2}$ is genotypic variance and $\sigma_{\mathrm{e}}^{2}$ is environmental variance. Since the genotypes used in this study were autogamous and genetically uniform, the expected mean squares for error was used to estimate the random environmental variance.

\section{Results and Discussion}

Significant genotypic differences were found for leafminer stings per unit leaf area in the field (Table 1). None of the 78 genotypes tested was immune to leafminers, as all genotypes had at least a few stings (Table 2). Mean number of leafminer stings

Table 1. Mean squares and selected contrasts from ANOVA of leafminer stings per $20-\mathrm{cm}^{2}$ leaf area of lettuces grown in the field in Salinas, Calif., in 2001 (35 genotypes) and 2002 (54 genotypes).

\begin{tabular}{|c|c|c|c|}
\hline \multirow{2}{*}{$\begin{array}{l}\text { Source of } \\
\text { variation }\end{array}$} & \multirow[b]{2}{*}{$\mathrm{df}^{\mathrm{z}}$} & \multicolumn{2}{|c|}{$\begin{array}{c}\text { Mean squares for } \\
\text { stings } / 20-\mathrm{cm}^{2} \text { leaf area }\end{array}$} \\
\hline & & 2001 & 2002 \\
\hline$\overline{\text { Block }}$ & 7 & 503.2 & $4,342.2^{* *}$ \\
\hline Genotype & $34(53)$ & $22,760.4^{* *}$ & $18,139.8^{* *}$ \\
\hline Wildy vs. cultivated & 1 & $165,281.1^{* *}$ & $360,181.9^{* *}$ \\
\hline Leaf and romaine vs. head & $\mathrm{d}^{\mathrm{x}} \quad 1$ & 825.0 & $2,260.2$ \\
\hline Leaf vs. romaine & 1 & $196,321.7^{* *}$ & $130,361.1^{* *}$ \\
\hline Butterhead vs. crisphead & 1 & $5,207.1^{* *}$ & $4,957.3^{*}$ \\
\hline Error & $238(371)$ & 624.7 & $1,032.6$ \\
\hline
\end{tabular}

${ }^{\mathrm{z}} \mathrm{df}=$ degree of freedom. Values in parenthesis are for 2002.

yWild species: Lactuca serriola, L. saligna, and L. virosa.

xHead types include butterhead and crisphead lettuces.

*** Significant $\mathrm{F}$ tests at $P=0.05$ or 0.01 , respectively. 
per $20-\mathrm{cm}^{2}$ leaf area ranged from 15.9 to 269.4 in 2001 and from 4.5 to 201.0 in 2002 for the genotypes tested. Wild species generally had low densities of leafminer stings in field tests. Among genotypes of L. sativa, 'Shining Star', PI 251247, PI 187238, 'Lolla Rossa', 'La Brillante', 'Merlot', and 'Bologna' had fewer stings per unit leaf area than other cultivars. 'Da Ye Wo Sun' and 'Iceberg' had the highest sting densities among genotypes tested. These results suggest that lettuce genotypes differ in their suitability as leafminer hosts in the field, and resistance to leafminers exists in different lettuce types and species.

Sting results from the field tests were highly correlated $(r=$ 0.770 for the 2001 test and 0.756 for the 2002 test) with the results for the same genotypes tested in insect cages in a previous study (Mou and Liu, 2003). The consistency in performance suggests that differences in resistance were stable and a cage test can be used to screen for leafminer resistance in the field. Broad-sense heritability estimates for leafminer stings per $20-\mathrm{cm}^{2}$ leaf area in the field were $81.6 \%$ for the 2001 test and $67.4 \%$ for the 2002 test, as compared to estimates of 64.8 and $65.2 \%$ obtained from two cage tests (Mou and Liu, 2003). Broad-sense heritability measures the portion of variation observed for a trait that is due to genetic or heritable cause, as opposed to environmental influence. It suggests that the number of stings per unit leaf area is a heritable trait and selection for this trait is likely to be effective.

When different types of lettuce were compared, wild species had significantly fewer leafminer stings than cultivated lettuces in the field (Tables 1 and 3). Transfer of resistance from wild species often brings in horticulturally undesirable traits that may need additional backcrosses to eliminate (Mou et al., 2004). Although it may be easier to use cultivated lettuce as sources of resistance in a breeding program, genes from wild species can be used to broaden the genetic base of resistance. Among the major cultivated types, leaf lettuce had the lowest sting density while romaine lettuce had the highest. Crisphead lettuce had fewer stings than the butterhead type. Nagata et al. (1998) suggested that a potential deficiency of a nutritional factor might be involved in conferring host plant resistance to leafminers (L. trifolii). Romaine lettuce generally has higher vitamin Aand vitamin C content than other lettuce types (U.S. Dept. of Agriculture, 2002). In previous tests conducted in insect cages, crisphead lettuce had most stings (Mou and Liu, 2003). The difference might be partly explained by the fact that the head types did not form tightly-packed heads in insect cages. Opening heads

Table 2. Means and least significant differences (LSD) at $P=0.05$ for number of leafminer stings per 20- $\mathrm{cm}^{2}$ leaf area of lettuce genotypes tested in the field in 2001 and 2002.

\begin{tabular}{|c|c|c|c|}
\hline \multirow[b]{2}{*}{ Genotype } & \multirow[b]{2}{*}{ Species, type } & \multicolumn{2}{|c|}{ Stings $/ 20-\mathrm{cm}^{2}$ leaf area } \\
\hline & & 2001 & 2002 \\
\hline PI 509525 & L. saligna & ---- & 4.5 \\
\hline PI 490999 & L. saligna & 15.9 & 11.4 \\
\hline PI 261653-1 & L. saligna & ---- & 19.1 \\
\hline PI 273597 & L. virosa & 22.8 & 27.6 \\
\hline PI 491181 & L. serriola & ---- & 29.5 \\
\hline Shining Star & L. sativa, leaf & ---- & 31.5 \\
\hline PI 251247 & L. sativa, primitive & ---- & 31.8 \\
\hline PI 274375 & L. virosa & 22.5 & 37.0 \\
\hline PI 187238 & L. sativa, leaf & ---- & 43.4 \\
\hline PI 491178 & L. serriola & ---- & 47.5 \\
\hline Lolla Rossa & L. sativa, leaf & 34.6 & 52.1 \\
\hline La Brillante & L. sativa, Batavia & ---- & 55.0 \\
\hline Merlot & L. sativa, leaf & 21.8 & 55.6 \\
\hline Bologna & L. sativa, leaf & ---- & 59.9 \\
\hline PI 274901 & L. virosa & ---- & 61.9 \\
\hline Batavia Lydia & L. sativa, Batavia & ---- & 71.3 \\
\hline Red Grenoble & L. sativa, Batavia & ---- & 76.9 \\
\hline Cosberg & L. sativa, crisphead & ---- & 84.6 \\
\hline Dark Green Boston & L. sativa, butterhead & ---- & 84.9 \\
\hline Big Boston & L. sativa, butterhead & ---- & 85.6 \\
\hline Syreka & L. sativa, leaf & ---- & 89.5 \\
\hline Acefield & L. sativa, crisphead & ---- & 99.4 \\
\hline PI 358003 & L. sativa, butterhead & ---- & 101.6 \\
\hline Jade & L. sativa, crisphead & ---- & 102.5 \\
\hline Calrico & L. sativa, crisphead & ---- & 103.1 \\
\hline PI $288244 a$ & L. sativa, Latin & ---- & 105.0 \\
\hline Alpi & L. sativa, romaine & ---- & 107.1 \\
\hline Salinas & L. sativa, crisphead & ---- & 107.8 \\
\hline Okayama & L. sativa, butterhead & ---- & 108.1 \\
\hline Great Lakes 65 & L. sativa, crisphead & ---- & 108.5 \\
\hline PI 491014 & L. sativa, Latin & ---- & 109.0 \\
\hline PI 323940 & L. sativa, Batavia & ---- & 109.3 \\
\hline King Crown & L. sativa, crisphead & 99.8 & 109.6 \\
\hline PI 342534 & L. sativa, butterhead & ---- & 110.3 \\
\hline PI 255568 & L. sativa, Batavia & ---- & 110.5 \\
\hline Achat & L. sativa, butterhead & ---- & 112.9 \\
\hline
\end{tabular}


Table 2. Continued.

\begin{tabular}{|c|c|c|c|}
\hline \multirow[b]{2}{*}{ Genotype } & \multirow[b]{2}{*}{ Species, type } & \multicolumn{2}{|c|}{ Stings $/ 20-\mathrm{cm}^{2}$ leaf area } \\
\hline & & 2001 & 2002 \\
\hline PI 212099 & L. sativa, leaf & ---- & 113.1 \\
\hline PI 507930 & L. sativa, crisphead & 75.6 & 120.0 \\
\hline Donia & L. sativa, butterhead & --- & 122.5 \\
\hline PI $358038 \mathrm{c}$ & L. sativa, romaine & 218.5 & 125.6 \\
\hline PI 491212 & L. sativa, romaine & ---- & 126.5 \\
\hline PI 344074 & L. sativa, romaine & ---- & 137.3 \\
\hline PI 491225 & L. sativa, romaine & ---- & 137.6 \\
\hline Cerise & L. sativa, leaf & ---- & 143.3 \\
\hline Bibb & L. sativa, butterhead & 72.6 & 143.6 \\
\hline Iceberg & L. sativa, Batavia & 269.4 & 143.6 \\
\hline Royal Oak Leaf & L. sativa, leaf & --- & 144.4 \\
\hline PI 491006 & L. sativa, romaine & ---- & 148.5 \\
\hline Deer's Tongue & L. sativa, leaf & --- & 153.9 \\
\hline Dark Green Cos & L. sativa, romaine & ---- & 166.4 \\
\hline Margarita & L. sativa, butterhead & 154.0 & 179.3 \\
\hline Lobjoits & L. sativa, romaine & --- & 180.6 \\
\hline Paris White & L. sativa, romaine & ---- & 196.3 \\
\hline Da Ye Wo Sun & L. sativa, stem & ---- & 201.0 \\
\hline PI 251245 & L. sativa, primitive & 41.4 & ---- \\
\hline Salad Bowl & L. sativa, leaf & 47.5 & ---- \\
\hline $801277-1$ & L. sativa, crisphead & 71.1 & ---- \\
\hline Ice Cube & L. sativa, crisphead & 76.8 & ---- \\
\hline Mohawk & L. sativa, crisphead & 88.0 & ---- \\
\hline Imperial & L. sativa, crisphead & 88.9 & ---- \\
\hline Alpen & L. sativa, crisphead & 92.3 & ---- \\
\hline PI 206963 & L. sativa, leaf & 93.4 & ---- \\
\hline Monterey & L. sativa, crisphead & 96.4 & ---- \\
\hline Great Lakes & L. sativa, crisphead & 96.6 & ---- \\
\hline Glacier & L. sativa, crisphead & 100.0 & ---- \\
\hline Niner & L. sativa, crisphead & 100.1 & ---- \\
\hline Francisco & L. sativa, crisphead & 100.4 & ---- \\
\hline Salinas 88 & L. sativa, crisphead & 101.9 & ---- \\
\hline Tiber & L. sativa, crisphead & 105.1 & ---- \\
\hline Polar & L. sativa, crisphead & 107.4 & ---- \\
\hline Climax & L. sativa, crisphead & 107.6 & ---- \\
\hline Vanguard & L. sativa, crisphead & 118.4 & ---- \\
\hline Valmaine & L. sativa, romaine & 127.1 & ---- \\
\hline Vitana & L. sativa, butterhead & 129.5 & ---- \\
\hline Calmar & L. sativa, crisphead & 131.1 & ---- \\
\hline Thompson & L. sativa, crisphead & 135.6 & ---- \\
\hline Eiffel Tower & L. sativa, romaine & 161.3 & ---- \\
\hline Etna & L. sativa, crisphead & 165.3 & ---- \\
\hline Mean & & 99.7 & 99.1 \\
\hline $\mathrm{LSD}_{0.05}$ & & 24.6 & 31.5 \\
\hline
\end{tabular}

Table 3. Mean and range of leafminer stings per 20- $\mathrm{cm}^{2}$ leaf area of different lettuce types from field experiments in Salinas, Calif., in 2001 and 2002.

\begin{tabular}{|c|c|c|c|c|c|c|}
\hline \multirow[b]{2}{*}{ Lettuce type } & \multicolumn{3}{|c|}{2001} & \multicolumn{3}{|c|}{2002} \\
\hline & $\mathrm{n}^{\mathrm{z}}$ & Mean & Range & $\mathrm{n}$ & Mean & Range \\
\hline Wild species & 3 & 20.4 & $15.9-22.5$ & 8 & 29.8 & $4.5-61.9$ \\
\hline Leaf & 4 & 49.3 & $21.8-93.4$ & 10 & 88.7 & $31.5-153.9$ \\
\hline Primitive & 1 & 41.4 & --- & 1 & 31.8 & --- \\
\hline Crisphead & 20 & 102.9 & $71.1-165.3$ & 8 & 104.4 & $84.6-120.0$ \\
\hline Latin & --- & --- & --- & 2 & 107.0 & $105.0-109.0$ \\
\hline Batavia & 1 & 269.4 & --- & 6 & 94.4 & $55.0-143.6$ \\
\hline Butterhead & 3 & 118.7 & $72.6-154.0$ & 9 & 116.5 & $84.9-179.3$ \\
\hline Romaine & 3 & 169.0 & $127.1-218.5$ & 9 & 147.3 & $107.1-196.3$ \\
\hline Stem & --- & --- & --- & 1 & 201.0 & --- \\
\hline
\end{tabular}

${ }^{\mathrm{z} N u m b e r}$ of genotypes in each lettuce type. 
Table 4. Correlation coefficients of traits from $112 \mathrm{~F}_{2}$ plants of crosses among different lettuce genotypes in the field in Salinas, Calif., in 2001.

\begin{tabular}{|c|c|c|c|c|c|c|c|}
\hline Traits $^{z}$ & $\begin{array}{c}\text { Avg } \\
\text { stings }\end{array}$ & $\begin{array}{c}\text { Max } \\
\text { stings }\end{array}$ & $\begin{array}{c}\text { Leaves } \\
\text { (no.) }\end{array}$ & $\begin{array}{c}\text { Leaf } \\
\text { wt }\end{array}$ & $\begin{array}{l}\text { Flies } \\
\text { (no.) }\end{array}$ & $\begin{array}{c}\text { Flies/ } \\
\text { kg leaves }\end{array}$ & $\begin{array}{l}\text { Wt/ } \\
\text { leaf }\end{array}$ \\
\hline$\overline{\text { Max stings }}$ & $0.912^{* *}$ & & & & & & \\
\hline Leaves & 0.109 & 0.014 & & & & & \\
\hline Leaf wt & $0.229^{*}$ & $0.294^{* * *}$ & 0.010 & & & & \\
\hline Flies & $0.244^{* *}$ & 0.176 & 0.051 & $0.342^{* *}$ & & & \\
\hline Flies/kg leaves & $0.195^{*}$ & 0.118 & 0.045 & 0.076 & $0.931^{* *}$ & & \\
\hline Wt/leaf & 0.158 & $0.260^{* *}$ & $-0.533^{* *}$ & $0.825^{* *}$ & $0.243^{* *}$ & 0.029 & \\
\hline Flies/leaf & $0.218^{*}$ & 0.166 & -0.147 & $0.337^{* *}$ & $0.961^{\text {*** }}$ & $0.898^{* *}$ & $0.357^{\text {*** }}$ \\
\hline
\end{tabular}

Traits. Avg stings = average leafminer stings per $20-\mathrm{cm}^{2}$ leaf area from five lower leaves of the lettuce plant. Max stings = highest leafminer sting density in $20-\mathrm{cm}^{2}$ leaf area from the five leaves counted. Leaves $=$ total number of leaves harvested from the plant. Leaf wt $=$ total fresh weight of leaves harvested from the plant. Flies $=$ total number of flies emerged from the harvested leaves of the plant. Flies $/ \mathrm{kg}$ leaves $=$ average number of flies emerged per $\mathrm{kg}$ harvested leaves. Wt/leaf = average weight per harvested leaf. Flies/leaf = average number of flies emerged from a harvested leaf.

**** Significant at $P=0.05$ or 0.01 , respectively.

Table 5. Correlation coefficients of traits from $120 \mathrm{~F}_{2}$ plants of crosses among different lettuce genotypes in the field in Salinas, Calif., in 2002.

\begin{tabular}{|c|c|c|c|c|c|c|c|c|c|}
\hline Traitsz $^{z}$ & $\begin{array}{l}\text { Stings/ } \\
20 \mathrm{~cm}^{2}\end{array}$ & $\begin{array}{c}\text { Leaves } \\
\text { (no.) }\end{array}$ & $\begin{array}{c}\text { Leaf } \\
\text { wt }\end{array}$ & $\begin{array}{c}\text { Pupae } \\
\text { (no.) }\end{array}$ & $\begin{array}{l}\text { Flies } \\
\text { (no.) }\end{array}$ & $\begin{array}{c}\text { Pupae/ } \\
\text { kg leaves }\end{array}$ & $\begin{array}{l}\mathrm{Wt} / \\
\text { leaf }\end{array}$ & $\begin{array}{c}\text { Flies/kg } \\
\text { leaves }\end{array}$ & $\begin{array}{c}\text { Pupae/ } \\
\text { leaf } \\
\end{array}$ \\
\hline Leaves & 0.004 & & & & & & & & \\
\hline Leaf weight & -0.079 & $0.351^{* *}$ & & & & & & & \\
\hline Pupae & $0.317^{* * *}$ & -0.058 & 0.067 & & & & & & \\
\hline Flies & 0.031 & 0.116 & $0.458^{* *}$ & $0.543^{* *}$ & & & & & \\
\hline Pupae/kg leaves & $0.410^{* *}$ & -0.192 & $-0.357^{* *}$ & $0.858^{* *}$ & $0.222^{*}$ & & & & \\
\hline Weight/leaf & -0.093 & -0.166 & $0.855^{* *}$ & 0.110 & $0.430^{* *}$ & $-0.276^{* *}$ & & & \\
\hline Flies/kg leaves & 0.102 & -0.042 & 0.059 & $0.627^{* * *}$ & $0.879^{* *}$ & $0.500^{* *}$ & 0.096 & & \\
\hline Pupae/leaf & $0.309^{* * *}$ & $-0.319^{* *}$ & -0.028 & $0.951^{* *}$ & $0.476^{* *}$ & $0.861^{* *}$ & 0.152 & $0.606^{* *}$ & \\
\hline Flies/leaf & 0.024 & -0.124 & $0.367^{* *}$ & $0.557^{* *}$ & $0.959^{* *}$ & $0.273^{* *}$ & $0.471^{* *}$ & $0.886^{* *}$ & $0.569^{* *}$ \\
\hline
\end{tabular}

${ }^{2}$ Traits. Stings $/ 20 \mathrm{~cm}^{2}=$ leafminer stings in a $20-\mathrm{cm}^{2}$ leaf area with the highest sting density on the selected plant. Leaves $=$ total number of leaves harvested from the plant. Leaf wt $=$ total fresh weight of leaves harvested from the plant. Pupae $=$ total number of pupae emerged from the harvested leaves of the plant. Flies = total number of flies emerged from the harvested leaves of the plant. Pupae $/ \mathrm{kg}$ leaves $=$ average number of pupae emerged per $\mathrm{kg}$ harvested leaves. $\mathrm{Wt} / \mathrm{leaf}=$ average weight per harvested leaf. Fly/kg leaves = average number of flies emerged per $\mathrm{kg}$ harvested leaves. Pupae/leaf $=$ average number of pupae emerged from a harvested leaf. Flies/leaf $=$ average number of flies emerged from a harvested leaf.

**** Significant at $P=0.05$ or 0.01 , respectively.

Table 6. Means and least significant differences (LSD) at $P=0.05$ for leafminer resistant traits of seven lettuce genotypes in a no-choice test in insect cages in 2002 .

\begin{tabular}{|c|c|c|c|c|c|}
\hline Genotype $^{z}$ & $\begin{array}{l}\text { Adult } \\
\text { period } \\
\text { (day) }\end{array}$ & $\begin{array}{l}\text { Stings/ } \\
20 \mathrm{~cm}^{2 y}\end{array}$ & $\begin{array}{c}\text { Stings/ } \\
\text { plant }\end{array}$ & $\begin{array}{c}\text { Mines/ } \\
\text { plant }\end{array}$ & $\begin{array}{l}\text { Flies } \\
\text { plant }^{\mathrm{x}}\end{array}$ \\
\hline PI 187238 & 5.3 & $32.3(43.4)$ & 205 & 5.7 & 0.4 \\
\hline PI 273597 (L. virosa) & 4.6 & $37.4(27.6)$ & 229 & 14.0 & 0.0 \\
\hline PI 491178 (L. serriola) & 6.0 & $49.1(47.5)$ & 138 & 1.1 & 0.4 \\
\hline PI 509525 (L. saligna) & 10.1 & $6.1(4.5)$ & 40 & 0.0 & 0.0 \\
\hline Red Grenoble & 9.4 & $53.0(76.9)$ & 402 & 29.0 & 0.6 \\
\hline Salinas & 8.9 & $385.0(107.8)$ & 2,923 & 5.7 & 5.1 \\
\hline Da Ye Wo Sun & 11.7 & $860.7(201.0)$ & 5,959 & 20.1 & 13.7 \\
\hline $\mathrm{LSD}_{0.05}$ & 2.1 & $146.4(31.5)$ & 1,268 & 4.6 & 3.4 \\
\hline
\end{tabular}

${ }^{2}$ All genotypes are L. sativa except those noted in parentheses.

yLeafminer stings per $20 \mathrm{~cm}^{2}$ leaf area, results in parentheses are from 2002 field (choice) test for comparison.

xNumber of flies emerged from each plant.

has been shown to increase the nutritional value of the plant (Mou and Ryder, 2004), which could in turn attract leafminers.

There was also variability in leafminer sting density within each lettuce type (Table 3). Leaf lettuce especially showed a wider range of variation in sting density than other lettuce types. The low mean and large variation of sting density in leaf lettuce suggest that resistance to leafminer stings might be easier to achieve in leaf lettuce than in other lettuce types.
Most stings are caused by the feeding activities of leafminer adult. The question arises whether leafminer flies tend to lay fewer eggs on a lettuce plant if they do not like to feed on that plant. Leafminer eggs are difficult to count because they are tiny and are laid within leaf tissue. Therefore, the number of pupae or flies that emerged from a plant was used as an indirect measure of eggs laid in the plant. Our $\mathrm{F}_{2}$ results (Table 4 and 5) indicate that the number of stings per unit leaf area was only moderately 
correlated with flies or pupae produced per plant or per kilogram of leaves. This suggests that feeding nonpreference does not necessarily mean oviposition-nonpreference for a lettuce genotype, and these two traits can be improved independently. Numbers of pupae and flies produced were also just moderately correlated (Table 5), suggesting that lettuce genotypes may play a role in pupa mortality. Number of pupae produced per plant or per leaf was not correlated with the total weight of leaves harvested from the plant or weight per leaf (Table 5). It suggests that leafminer flies did not lay their eggs randomly, and oviposition-nonpreference occurred in these plants.

To study the mechanism of leafminer resistance in lettuce, we subjected resistant and susceptible genotypes in field (choice) tests to a no-choice test. Leafminer adult survived $11.7 \mathrm{~d}$ on 'Da Ye Wo Sun', but only 4.6 d on PI 273597 (L. virosa, Table 6). Although there were mines on $L$. virosa plants, the mines did not enlarge and remained narrow and short, resulting in no fly emergence. This phenomenon was also observed in the field. Coupled with the short adult survival period on the accession, it suggests that $L$. virosa is toxic (antibiotic) to leafminers. If this type of resistance is used, it may reduce the leafminer population and reproduction, but still result in some damages from stings and mines. In comparison with PI 273597, PI 187238 had about the same adult survival period and number of stings but fewer mines (Table 6), and it may be easier to transfer the resistance from it to other cultivars than from wild species. Leafminer adult survived longer on PI 509525 (L. saligna) than on most other genotypes but had few stings and no mines or fly emergence, suggesting a deterrent for feeding and oviposition might be involved (Table 6). If this type of resistance is utilized, damages from stings and mines may be reduced but adult flies might survive a longer period of time and could move to other fields or crops, as compared to the type of resistance conferred by PI 273597. These results suggest that there are different mechanisms by which different Lactuca species resist leafminers. It may be desirable to combine different types of resistance in a lettuce cultivar through plant breeding.

In the choice tests, fewer stings per unit leaf area suggest host nonpreference. Resistance based on antixenosis would be desirable because even the photosynthetic losses caused by adult feeding and oviposition would be reduced (Trumble et al., 1985). When nonpreference type of resistance is employed, there is always a concern that insect may choose the nonpreferred host when the preferred one is not present (Ryder, 1986). In our no-choice test, genotypes with fewer stings in field (choice) tests also had fewer stings per unit leaf area and per plant, and less fly emergence than genotypes with higher sting densities in field tests (Table 6). This suggests that resistant genotypes from choice tests are still resistant to leafminers under no-choice conditions, and sting density can be used to effectively select for leafminer resistance. This is good news for plant breeders as they can just select leafminer-resistant plants in choice tests that are much easier to conduct than nochoice tests that require isolation of individual genotype.

We found a wide range of genetic variability in leafminer resistance in different types and species of lettuce. Results suggest that both antixenosis and antibiosis exist in lettuce germplasm and resistant genotypes from choice test remain resistant under no-choice conditions. Coupled with the relatively high heritability estimates for number of stings per unit leaf area, genetic improvement of lettuce for leafminer resistance seems feasible. We are currently incorporating the resistant sources found in this study into elite cultivars in a lettuce breeding program.

\section{Literature Cited}

Erb, W.A., R.K. Lindquist, N.J. Flickinger, and M.L. Casey. 1993. Resistance of selected interspecific Lycopersicon hybrids to Liriomyza trifolii (Diptera:Agromyzidae). J. Econ. Entomol. 86:100-109.

Keil, C.B. and M.P. Parrella. 1990. Characterization of insecticide resistance in two colonies of Liriomyza trifolii (Diptera: Agromyzidae). J. Econ. Entomol. 83:18-26.

LeStrange, M., S. Koike, J. Valencia, and W. Chaney. 1999. Spinach production in California. Univ. Calif. Div. Agr. Nat. Resour. Publ. 7212, p. 3-4.

Mason, G.A., M.W. Johnson, and B.E. Tabashnik. 1987. Susceptibility of Liriomyza sativae and Liriomyza trifolii (Diptera:Agromyzidae) to permethrin and fenvalerate. J. Econ. Entomol. 80:1262-1266.

Morgan, D.J.W., S.R. Reitz, P.W. Atkinson, and J.T. Trumble. 2000. The resolution of Californian populations of Liriomyza huidobrensis and Liriomyza trifolii (Diptera: Agromyzidae) using PCR. Heredity 85:53-61.

Mou, B. and Y. B. Liu. 2003. Leafminer resistance in lettuce. HortScience 38:570-572.

Mou, B. and E.J. Ryder. 2004. Relationship between the nutritional value and the head structure of lettuce. Acta Hort. (in press).

Mou, B., E.J. Ryder, J. Tanaka, Y. B. Liu, and W.E. Chaney. 2004. Breeding for resistance to leafminer in lettuce. Acta Hort. (in press).

Nagata, R.T., L.M. Wilkinson, and G.S. Nuessly. 1998. Longevity, fecundity, and leaf stippling of Liriomyza trifolii (Diptera: Agromyzidae) as affected by lettuce cultivar and supplemental feeding. J. Econ. Entomol. 91:999-1004.

Nuessly, G.S. and R.T. Nagata. 1994. Differential probing response of Serpentine leafminer, Liriomyza trifolii (Burgess), on cos lettuce. J. Entomol. Sci. 29:330-338.

Parrella, M.P. 1987. Biology of Liriomyza. Annu. Rev. Entomol. 32: 201-224.

Parrella, M.P. and J.T. Trumble. 1989. Decline of resistance in Liriomyza trifolii (Diptera: Agromyzidae) in the absence of insecticide selection pressure. J. Econ. Entomol. 82:365-368.

Petersen, R. G. 1985. Design and analysis of experiments, p. 85-111. Marcel Dekker, Inc., New York.

Ryder, E.J. 1986. Lettuce breeding, p. 433-474. In: M.J. Bassett (ed.). Breeding vegetable crops. AVI Publ. Co., Westport, Conn.

Scheffer, S.J., A. Wijesekara, D. Visser, and R.H. Hallett. 2001. Polymerase chain reaction-restriction fragment-length polymorphism method to distinguish Liriomyza huidobrensis from L. langei (Diptera: Agromyzidae) applied to three recent leafminer invasions. J. Econ. Entomol. 94:1177-1182.

Singh, R.K. and B.D. Chaudhary. 1977. Biometrical methods in quantitative genetic analysis, p. 52-54. Kalyani Publ., New Delhi, India.

Trumble, J.T., W. Dercks, C.F. Quiros, and R.C. Beier. 1990. Host plant resistance and linear furanocoumarin content of Apium accessions. J. Econ. Entomol. 83:519-525.

Trumble, J.T. and C.F. Quiros. 1988. Antixenotic and antibiotic resistance in Apium species to Liriomyza trifolii (Diptera: Agromyzidae). J. Econ. Entomol. 81:602-607.

Trumble, J.T., I. Ting, and L. Bates. 1985. Analysis of physiological, growth, and yield responses of celery to Liriomyza trifolii. Entomol. Expt. Appl. 38:15-21.

University of California. 1992. Integrated pest management for cole crops and lettuce, p. 31-32. Statewide Integrated Pest Mgt. Project, Div. Agr. Nat. Resour. Publ. 3307.

U.S. Dept. of Agriculture, Agricultural Research Service. 2002. USDA national nutrient database for standard reference. Release 15. Nutrient data laboratory. http://www.nal.usda.gov/fnic/foodcomp. 